\title{
AWARENESS AND PRACTICE OF UNIVERSAL PRECAUTIONS BY HEALTH CARE WORKERS IN A TEACHING INSTITUTE
}

\author{
Dargan $\mathbf{P}^{1}$, Thakur $\mathbf{S}^{1}$, \\ Jain $\mathbf{B} \mathbf{K}^{1}$, Singh $\mathbf{R}^{1}$, Deb $\mathbf{M}^{1}$
}

\section{ABSTRACT}

Health Care Workers (HCWs) face a grave risk of acquiring infection including Human Immunodeficiency Virus (HIV) and Hepatitis B \& C during the course of their work. A questionnaire based study was conducted amongst the $154 \mathrm{HCWs}$ working in a teaching hospital to study Acquired Immunodeficiency Syndrome (AIDS) awareness, and to assess the knowledge, attitude, and practice in respect of application of universal precautions. This study has shown that definite lacunae exist regarding awareness and practice of universal precautions. Comprehensive in service educational programme for HCWs regarding the implementation of universal precautions is recommended.

Key Words: HIV, Health Care Workers, Universal Precautions.

\section{INTRODUCTION}

The AIDS epidemic has brought into focus that health care workers (HCWs) could become infected with diseases harbored by their patients. The US Center for Disease Control and several other authorities have prescribed guidelines for protection of HCWs from occupational exposure. The efficiency of these recommendations in minimizing the risk of percutaneous, mucous membrane, and cutaneous exposure to blood and blood containing body fluids has been assessed in several settings. ${ }^{1,2,4} \mathrm{~A}$ temporal association between implementation of these recommendations and a sustained decrease in parenteral exposure to infection amongst hospital personnel has been demonstrated. ${ }^{2,3,4}$ Several reasons have been cited for non-compliance among $\mathrm{HCW}$ in putting universal precautions into practice. ${ }^{5,6,7}$ This study was undertaken to assess the awareness and practice of Universal precautions by HCW's and to find the lacunae in implementation of universal precautions in B. P. Koirala Institute of Health Sciences, Dharan.

1. B. P. Koirala Institute of Health Sciences, (BPKIHS) Dharan, Nepal.

Address for correspondence : Dr. Puneet Dargan

F-7 D, SFS Flats, Saket

New Delhi - 17, India. 


\section{MATERIALS AND METHODS}

A personally administered questionnaire survey regarding awareness and practice of universal precautions was under taken amongst $154 \mathrm{HCWs}$ at BP Koirala Institute of Health Sciences (BPKIHS). This study was conducted over a two weeks period. The participants included nursing staff $(n=70)$, laboratory personnel $(n=24)$ and domiciliary workers $(n=60)$. All the participants responded.

\section{RESULTS \& DISCUSSION}

All the respondents (100\%) were aware of AIDS and its transmission by blood and body fluids. The awareness of vertical transmission was poor (14\%). Significantly, none of the domiciliary workers were aware of it. Needle stick injury was identified as a source of infection by only $55 \%$. Maximum awareness was observed among the nursing staff (71\%) and minimum among the domiciliary workers $(30 \%)$. Eighty-three $(54 \%) \mathrm{HCWs}$ identified saliva as an infective source as well. Appropriate barrier precautions were routinely used by 97 (63\%) HCWs but only 43 (28\%) practiced hand washing after degloving. A majority of nurses were unaware that an accidental exposure needs to be reported to the authority. Use of puncture proof container was practiced by $62 \%$ of HCWs. These and other results tabulated in Table 1 demonstrate definite lacunae in the successful implementation of universal precautions. It is evident from the responses that not all HCWs were aware of modes of infection, need for protective attire other than gloves, and appropriate disposal technique for blood stained waste.

The results of this study is in concordance with earlier findings by several workers, who have addressed this problem and identified several factors for noncompliance. Some of these are inability to
Table 1

Awareness and practice of Universal Precautions by Health Care Workers $(n=154)$.

\begin{tabular}{|c|c|c|c|c|}
\hline Item & $\begin{array}{c}\text { Nursing } \\
\text { Staff } \\
(\mathrm{n}-70)\end{array}$ & $\begin{array}{c}\text { Laboratory } \\
\text { Personnel } \\
(\mathrm{n}-24)\end{array}$ & $\begin{array}{c}\text { Domiciliary } \\
\text { Workers } \\
(\mathrm{n}-60)\end{array}$ & $\begin{array}{c}\text { Total } \\
(\mathrm{n}=154)\end{array}$ \\
\hline $\begin{array}{c}\text { Awareness of } \\
\text { needlestick injury } \\
\text { as an infective } \\
\text { source }\end{array}$ & $50(71)$ & $16(67)$ & $18(30)$ & $55 \%$ \\
\hline $\begin{array}{c}\text { Use of protective } \\
\text { attire other than } \\
\text { gloves. }\end{array}$ & $20(29)$ & $6(23)$ & $14(23)$ & $26 \%$ \\
\hline $\begin{array}{c}\text { Reporting of } \\
\text { Accidental } \\
\text { exposure }\end{array}$ & $12(17)$ & $7(30)$ & $46(77)$ & $42 \%$ \\
\hline $\begin{array}{c}\text { Doctors and } \\
\text { Seniors as sources } \\
\text { of information }\end{array}$ & $25(36)$ & $16(67)$ & $37(62)$ & $51 \%$ \\
\hline
\end{tabular}

Figures in parentheses denote percentage.

perceive risk, risk taking personality, inadequate knowledge and training facilities and perceived lack of organizational commitment to safety. ${ }^{8,9,10}$

Universal precautions are based on the premise that all patients be considered as sources of infection. Even a single area of non-compliance of prescribed precautions raises the possibility of occupational exposure.

Therefore, a proposal is made for an education programme for HCWs at BPKIHS which is target specific. Doctors and senior colleagues have been perceived as important sources of education by HCWs. The educational programme would therefore utilize the senior medical and nursing personnel for dissemination of information and implementation of the universal precautions in daily practice.

\section{CONCLUSION}

In view of the existing lacunae in awareness and practice of Universal Precautions, comprehensive in service training is recommended to all categories of HCWs in order to boost their existing knowledge and to motivate them to practice the measures related to universal precautions. 


\section{REFERENCES}

1. Wong E, Stotka J, Chinchilli V, et al. Are Universal Precautions effective in reducing the number of occupational exposures among health care workers. A prospective study of physicians on a medical service. JAMA. 1991; 265: 1123-8.

2 Doebbeling $B$, Wenzel R. The direct costs of Universal Precautions in a teaching hospital. JAMA. 1990; 264:2083-7.

3. Beckmann $\mathrm{SE}$, Vlahov $\mathrm{D}$, Kozial $\mathrm{DE}$, et al. Temporal association between implementation of Universal Precautions (UP) and a decrease in reported parenteral exposures (PE) to blood in health care workers. 32nd Interscience conference on Antimicrobial agents and Chemotherapy . Anaheim, California; American Society of Microbiology, 1992: Abstract 1191.

4. Haiduen D, De Maio T, Stevens D. A five year study of needle stick injuries: Significant reduction associated with conmunication, education and convenient placement of shanps containers. Infect Control Hosp Epidemiol. 1992:13:265-71. booky fluids before and after Universal Precautions training. Am J Med. 1991; 90:145-53.

6. Hammond JS, Eckes JM, Gomez GA, et al. HIV, trauma and infection control : Universal Precautions are universally ignored. J Trauma. 1990; 30:555-8.

7. Jagger J, Pearson R. Universal Precautions: Still missing the point of needle sticks. Infect Control Hosp Epidemiol. 1991; 12:211-3.

8. Odujinrin OM, Adegoke OA. AIDS; awareness and blood handling practices of health care workers in Lagos, Nigeria. Eur-J-Epidemiol. 1995.11 (4) :425-30.

9. Knight VM, Bodsworth NJ. Perceptions and practice of universal blood and body fluid precautions by registered nurses at a major Sydney teaching hospital. J-Adv-Nurs.1998. 27 (4) : 746-51.

10. Menon V, Bharucha K. Acquired immunodeficiency syndrome and health care professionals. J-Assoc-Physicians-India. 1994.42 (1) :22-3.

5. Fahey BJ, Koziol DE, Banks S, et al. Frequency of non parenteral occupational exposures to blood and

\section{Second SIOP - Asia Conference}

The $2^{\text {nd }}$ SIOP-Asia conference is being held in New Delhi, from November 22-24, 2002, under the auspices of the International Society of Pediatric Oncology (SIOP), the Pediatric Hematology Oncology Chapter (PHO) of IAP, the International Confederation of Childhood Cancer Parent Organization (ICCCPO), the International Network for Cancer Treatment and Research (INCTR), the Indian Society of Medical and Pediatric Oncology (ISMPO), and the All India Institute of Medical Sciences (AIIMS), New Delhi.

The Conference aims to bring together pediatric oncologists, hematologists, pediatricians, surgical oncologists and radiotherapists, practicing in the developing world, on a common platform with leading pediatric oncologists of the world.

With the central theme being "Childhood Cancer is Curable", the conference hopes to initiate a concerted effort in forging better links between parents and healthcare professionals.

\section{For further information please contact:}

Prof. L.S. Arya, Organizing Secretary

Department of Pediatrics, Division of Pediatric Oncology,

All India Institute of Medical Sciences, Ansari Nagar, New Delhi - 110 029, India.

Tel: 91-116594610, 6593209, 6864851 Ext-4390, 4610, Fax: 91-11-6862663

Email: Isarya@rediffmail.com 